\title{
There is no such thing as free higher education: A global perspective on the (many) realities of free systems
}

\author{
In the past few years, many countries around the world have debated the financing of \\ higher education. Increasingly, claims emerge that higher education should be free. \\ This article analyses the rationales behind the establishment and sustaining of free \\ tuition higher education systems to understand the current fervour. It then outlines the \\ global contemporary landscape of free higher education, by taking a close look at those \\ countries that currently have free higher education and what is meant by 'free' in \\ different contexts. The many realities behind the term 'free higher education' show that \\ it is a policy that is hard to sustain and hides many different scenarios, notably in terms \\ of access and success in higher education.
}

Keywords: free tuition; free higher education; comparative education; student costs; student financial aid

\section{Introduction}

Free higher education is, without doubt, on the global higher education agenda. Countries as varied as Chile, the United States, the United Kingdom, the Philippines, South Africa, and most recently, New Zealand, have been debating the issue during the past five years. In most cases, the call for free tuition first came from an opposition party during an election, and although the candidates were not always successful, they always gained significant popularity by supporting this policy. In some cases, namely Chile, the Philippines, and New Zealand, this has led to the implementation of such a policy.

As debates spark around the globe, the media and public attention given to advocates 
of free tuition focuses on financial issues. Most countries where free higher education is on the agenda have high tuition fees that have spiked in recent years. These fees are made affordable through the use of student loans, which have risen in parallel. As a result, graduates in countries like Chile, the United Kingdom, South Africa, and the United States have been crippled with student debt. Students have taken to the street to denounce these conditions and the early weakening of their financial capabilities. In these countries, free tuition has been presented as the ideal solution by many students and policy-makers.

In such a context, it is surprising that countries where free higher education is already implemented and sustained have not been under greater scrutiny. The global landscape of free higher education countries, what they have in common, and the efficiency of their higher education systems remain unexplored.

This paper aims to fill this gap in the academic literature. It explores the philosophical rationales behind the idea of free tuition, before describing the current global landscape of free higher education systems and the many different realities behind the label 'free higher education.' Finally, it looks at access and success in countries with free higher education, revealing these countries to face similar issues as those charging tuition fees.

This paper deliberately focuses on free tuition higher education, and therefore does not address cost-sharing policies and their rationales in countries that charge tuition fees, a task that has been undertaken elsewhere in the literature.

\section{Rationales behind free tuition higher education}

While many countries have attempted to eliminate or reduce the scope of their free tuition higher education systems, economic, social, philosophical and cultural rationales make it difficult for them to change. These rationales explain why free tuition higher education has persisted and is sustained today across many countries. 


\section{Higher education as a public good}

The most commonly used, and often the most criticised, argument advocating free higher education is that it is a public good. Samuelson (1954) described public goods as nonrivalrous and non-excludable, i.e. goods that can be consumed without leading to their exhaustion and goods whose benefits extend beyond the consumer (Marginson, 2007; Samuelson, 1954). Unfortunately, higher education does not fully comply with this definition: it has private benefits, thus making it excludable, and the best institutions have a limited number of seats, making entry rivalrous (Marginson, 2007). Therefore, academics have been trying to reconcile higher education's public benefits with the theory by emphasising externalities (Woolley, 2006) or drafting new definitions (Marginson, 2007). Despite these theoretical disputes, general agreement exists that higher education provides benefits to society, thus making it a positive investment for the 'public good.'

\section{Economic benefits}

The theory of human capital posits that capital is not limited to financial and physical assets, but exists under other forms, explaining the difference between economic growth and investment in traditional forms of capital (Becker, 1975; Mincer, 1981; Schultz, 1961). This form of capital is referred to as human capital 'because people cannot be separated from their knowledge, skills, health, or values in the way they can be separated from their financial and physical assets' (Becker, 2007, 248). Education is an example.

The impact of human capital on national economic growth implies that educating a whole population has advantages for society. This idea is supported by Solow's macroeconomic model that emphasizes the importance of labour quality - i.e., human capital - for economic national growth (Mankiw et al., 1990) and highlights the complementarity of human and physical capital. This complementarity is also highlighted by Mincer (1981) for 
whom human capital participates in the national economy by being a factor of production as well as a source of technological improvement through the generation of new knowledge (Bloom et al., 2007; Institute for Higher Education Policy [IHEP], 1998; Vossensteyn, 2009). Higher education may, therefore, have a multiplicative effect not only impacting the type of labour available but also the technologies. This theory is supported by Becker's recognition that higher education is essential because 'economic growth closely depends on the synergies between new knowledge and human capital' (2007, 248). In today's knowledge society, higher education could be considered one of the noblest forms of human capital.

Although human capital theory insists particularly on improved productivity gained through education, other public economic benefits exist; including increased tax revenue, higher consumption, increased workforce flexibility, lower reliance on government financial support, and better health (Bloom et al., 2007; IHEP, 1998; Organisation for Economic Cooperation and Development [OECD], 2014; Vossensteyn, 2009). Further evidence also suggests that educated workers are likely to postpone retirement (Peracchi and Welch, 1994), making them productive for longer in the workforce and better financially prepared for retirement (Lusardi and Mitchelli, 2007). These rationales make higher education particularly valuable to the economic wellbeing of societies.

\section{Social benefits}

The benefits of human capital extend beyond the economic realm to create social externalities (i.e., positive spillover for the society that also contribute to economic growth and development). As a form of human capital, higher education has many externalities that contribute to the enrichment of society (e.g., Bloom et al., 2007; Brennan et al., 2013; IHEP, 1998; OECD, 2014; Pusser, 2002; Vossensteyn, 2009). 
At a local level, educated workers contribute positively to the community by improving the performance of non-educated workers working alongside them and creating more and larger firms (Bloom et al., 2007). Other externalities suggested in the literature include reduced crime rate, less poverty, more social cohesion, more tolerance to diversity, more happiness in the community, more donations to charity, and more participation in community service (Bloom et al., 2007; Brennan et al., 2013; IHEP, 1998; OECD, 2014; Putnam, 2001; Uslaner, n.d.; Vossensteyn, 2009).

Human capital gained through higher education also has positive externalities beyond the community level, in particular through better citizenship. Individuals with college degrees are more likely to believe that they have a say in the government (OECD, 2014), to vote, write to politicians, and attend local political meetings (IHEP, 1998; Uslaner, n.d; Vossensteyn, 2009). Putnam (2001), as well as Rosenstone and Hansen (1993), agree that education is paramount to improving civic engagement, something that is necessary for fostering social capital through building a sense of citizenship. Moreover, Collins and Rhoads (2008) maintain that higher education is a tool to achieve nation-building, as it favours the conservation of local traditions and the advancement of national identity. In this area, philosophers agree with economists in acknowledging the value of higher education for democracy, since it trains citizens who take care, sustain and improve democracy (Dewey, 1916; Gutmann, 1999), although this arguably mostly applies to democratic nations and is therefore contingent on the political environment.

Though little quantitative evidence exists on the extent of higher education's externalities, probably more numerous than those suggested here, most economists agree that higher education improves society. Higher education also participates globally in the production of knowledge, the development of advanced literacy, the fostering of culture, and the balancing of social opportunities, all of which can be considered public goods 
(Marginson, 2007; Stiglitz, 1999). Therefore higher education is an enterprise that, independently of the context or financing mechanism, has a paramount public impact, both economically and socially, providing a strong argument for society to finance it.

\section{Higher education as a right}

Another argument used to substantiate the argument for free higher education is that higher education is a right and should, therefore, be made available to all without any obstacle to access. Indeed, Power assesses that if education is considered a right, 'every person in society is entitled to equality of educational opportunity. If obstacles to opportunity exist, they should be removed' $(1982,213)$. Two theories can be used to defend the right to higher education: the social and the justice theories.

\section{Higher education as a social right}

T. H. Marshall (1950) was the first to define social rights and what welfare states should provide to their citizens. He stated that citizenship is a 'principle of equality' (Marshall, 1950, 33) and defined the social element of citizenship as:

the whole range from the right to a modicum of economic welfare and security to the right to share to the full in the social heritage and to live the life of a civilised being according to the standards prevailing in the society. (Marshall, 1950, 11)

The last part of this definition is fundamental and states that every citizen has the right to live according to the standard of their society. The exponential massification of higher education (the gross enrolment ratio now exceeds 50 percent in many developed economies) means that higher education is the current norm. While developing economies have not reached these levels yet, it is very likely that universal higher education will be a global standard in the future. 
T. H. Marshall (1950) also emphasises that the right to education is entangled with a duty for citizens to be the best they can for society's sake - it can be argued that the needs of the knowledge society depend on tertiary educated citizens. He goes further, stating that the right to a certain standard of education is necessary for the quality of citizens and the 'health' of society. He agrees that this will not erase inequalities between social classes, but will allow some type of justice by levelling the playing field of opportunities at the scale of the citizen: 'the equality implicit in the concept of citizenship, even though limited in content, undermined the inequality of the class system, which was in principle a total inequality' (Marshall, 1950, 30).

Using this definition, there is no denying that higher education is a social right in contemporary society. Therefore, the state should take responsibility for providing such a right to its citizens.

\section{Higher education as a just right}

Higher education can also be considered a just right, since refusing access to higher education to part of the population or erecting barriers preventing access for some fosters inequalities and is therefore unjust. Only by making higher education a right can it cease being a vehicle for injustice and become a tool for justice in society.

In his seminal work, A Theory of Justice, Rawls (1999) affirms the importance of justice as a virtue to build a fair and equal society. Rawls puts the principle of justice above any other paradigm in the governance of social institutions and argues for just equality. This can only be achieved through the use of rights by the state to mitigate the inequalities that are inherent in contemporary societies. Rights should aim at improving the well-being of those who are worst off. 
Higher education represents an unfairly distributed resource, since students from high socio-economic backgrounds have better access to it and more success (Forsyth and Furlong, 2000; James, 2002). This unjustly deprives some citizens of resources enabling them to improve their future opportunities. In fact, better equity in access to higher education would improve equity in the labour market. This addresses the second part of the second principle of justice according to Rawls: 'social and economic inequalities are to be arranged so that they are $[\ldots]$ attached to offices and positions open to all under conditions of fair equality of opportunity' (Rawls 1999/1971, 266). Higher education is also unfair because it privileges a group that does not need the privilege; the system should instead be biased towards lower socio-economic strata. This agrees with the first part of Rawls' second principle for justice, also known as the difference principle: 'social and economic inequalities are to be arranged so that they are $[\ldots]$ to the greatest benefit of the least advantaged, consistent with the just savings principle’ (Rawls, 1999/1971, 266).

Higher education can therefore be considered a social right, in the welfare tradition, and a just right, in the justice tradition. In both cases, higher education as a right is a strong argument for advocates of free higher education, since tuition fees can be considered an obstacle to access, especially for the poorest.

\section{The information asymmetry}

Another rationale behind free higher education is that would-be students are unable to make a fully-informed decision. Higher education can indeed be defined as a merit good, which means that its benefits are not fully recognised by the population. In the first account of what he called 'merit wants,' Musgrave (1959) defined them as goods that are so beneficial they are financed by the state beyond what would be possible without government intervention. The consumption of merit goods would be low if the choice fell solely upon the citizen and 
the market, therefore this good 'merits' a better status. Education was one of the first clearly identified merit goods, health being another example. It is easy to extend this classification to higher education, not only because private benefits covering a life span are hard to conceptualise for young adults, but also because of the previously discussed public benefits and externalities.

The problem with goods that are deemed 'merit' is that information asymmetry or bounded rationality may lead to poor choices. Head recognised that 'distorted preferences constitute the essence of the merit good problem' $(1966,3)$. Imperfect knowledge can lead to both uncertainty and irrationality; both are paramount when considering higher education. Uncertainty exists because students are seldom aware of higher education's benefits. Irrationality occurs when individuals choose the workforce over tertiary education, valuing current income over higher future earnings, for instance.

With the inflation of higher education costs, the rise of cost-sharing, high opportunity costs, and ill-defined long-term benefits, there is no question that higher education is a complex investment decision for students. Yet states have extensive knowledge, based on years of research and practice, of the benefits of higher education - recognised widely by international organisations - and should be more rational. They should invest in higher education to enable citizens to benefit from their education to an extent that they cannot acknowledge.

\section{The need for 'equal opportunity'}

Last but not least, free tuition is often seen as an effective way to ensure equal opportunities. Equal opportunities insist that every student should have the same chances to enter higher education, independently of their socio-economic background, race, religion, or other differentiating factors. 
Coleman describes equality of opportunities in education as a state 'when the community provides the same resources, the same facilities, to all children' $(1969,347)$. He argues that it equates the 'idea that opportunity consist[s] of free and open access to the same school resources for all children' (Coleman, 1969, 348), affirming that such equality is only possible if education is free for all. Coleman's deeper analysis recognises that students should have access to equal resources efficient enough to erase the disparities created by familial backgrounds. It could be argued that higher education is such a resource - based on its economic and social positive impacts, as well as its potential to foster social mobility.

In trying to understand the funding of higher education in Europe, Blaug and Woodhall remarked that rationales for free higher education are based on the belief that 'it is necessary to provide free education at all levels and also to subsidise students' living expenses in post-secondary schooling so as to guarantee 'equality of educational opportunity"' (1978, 352). In Europe, free higher education is seen as a tool to make universities equally accessible to all. Since state subsidies favour the least-economically advantaged of our society, preventing higher education from being the privilege of the elite, they are the guardian of equal opportunities. Tilak acknowledges that 'the concern for equality of opportunity has led to almost universal agreement that the government should subsidise education' (2004, 6-7).

Philosophical theories behind the rationales for free higher education touch upon sensitive subjects such as the public good, equality and equity. The debate about equality is especially important, at a time when a tertiary qualification has become the norm in the knowledge society. As the cost of higher education rises in parallel with cost-sharing policies, tuition fees are seen as the main barrier to access, and free tuition as the logical solution. The public good rationale only reinforces the sentiment that higher education should be paid for by taxpayers' money, as society is a major beneficiary of a tertiary-educated population. The 
strength of the philosophical arguments behind free tuition explains why bastions of free tuition higher education systems remain strong and why there is such general resistance to tuition fees. Although most of the arguments above can also be used to support subsidised (but not free) higher education, they are highlighted here because they play an essential role in the free tuition debate. There are similarly strong arguments underlying the current global trend towards greater cost-sharing, but these would be beyond the scope of this article.

\section{Landscape and History}

Johnstone and Marcucci (2010) provided a list of 48 countries where public institutions do not charge tuition fees to students, excluding countries that implemented dual-track systems - some of which still provide an important share of students with free higher education. A revision of this list included 50 countries with no fees or only nominal fees (Marcucci, 2013). More recently, the World Policy Analysis Center (2017) monitored whether countries report the existence of tuition fees or not in the public higher education sector. An early report counted a total of 79 countries reporting no tuition fees: 16 lowincome, 41 middle-income, and 22 high-income (Heymann and McNeill, 2013). The current updated map totals 81 free tuition systems.

A comparison of the previous sources, and further research in case of contradiction, with additional updating from recent reforms, led to a total of 81 countries that offer some type of free tuition higher education (see Figure 1), to which Scotland should be added. The majority are located in Europe and Central Asia (30) and Sub-Saharan Africa (20). Although the Middle East and North Africa have fewer free countries in absolute number, more than 60 percent of the systems in this region can be considered free tuition. With only 4 free tertiary systems of education, East Asia and South Asia seem to have well-developed and accepted cost-sharing mechanisms. 
The geographic distribution of this information provides a pattern of country clusters that have some kind of free public higher education. Four main clusters can be distinguished: Latin America, the Middle East and North Africa, the Nordic countries, and transitional (or ex-Soviet) countries.

Each cluster includes very different countries at various stages of economic development (see Figure 2), emphasizing the omnipresence of free tuition systems among countries that have little in common. Using the World Bank classification, I calculate that 25 free systems are in high-income and 20 are in upper-middle income countries (32 and 36 percent of the respective income categories). With a further 42 percent of lower middleincome countries (22) and 45 percent of low-income ones (14), there is a balance of all income types across the countries. Therefore, free tuition higher education does not seem to be limited to developed economies - if anything a higher share of countries with lower income levels have free systems, and their reason for existence can be found in historical or political contexts rather than economic ones.

\section{[Figures 1 and 2 about here]}

The historic rationales behind these countries' free higher education vary widely, revealing the importance given to education by different political systems. The Nordic countries have always been considered emblems of the welfare state (West, 2013): the importance they place on human beings and social equity makes it inevitable that they support free higher education for all - the social right argument. Transitional countries owe their free tuition system to their communist past (Johnstone and Marcucci, 2010), and the desire to abolish social classes through a completely egalitarian system - the equal opportunity argument. The socialist-Marxist view is also said to have influenced East African countries in their decision to keep free systems of higher education (Johnstone and Marcucci, 
2010). In Latin America, free tuition is anchored in the view of higher education as a basic social obligation - a social right - and a deep mistrust of the private sector (Adrian, 1983). To this day, the social role of the university remains extremely important in this region.

\section{The various forms of free tuition higher education}

Even though the countries above propose some type of free higher education, most fail to live up to the ideal of offering free access for all to public higher education. Faced with financing challenges, countries offering free public higher education have established hidden cost-sharing mechanisms to alleviate the cost borne by governments. These maintain the pretence of free tuition, while generating revenues. Three main cost-sharing systems have been implemented in countries priding themselves on offering free public higher education: the establishment of non-tuition fees, the use of dual track systems, and the restriction of the number of fully-subsidised seats in public higher education institutions (Johnstone and Marcucci, 2010; Marcucci and Usher, 2012). Student loan mechanisms enabling free tuition at the point of entry but explicitly expecting repayment are not discussed here since tuition fees are an inclusive part of these systems.

\section{Non-tuition fees}

Non-tuition fees are fees charged independently of tuition fees to cover non-instructional university expenses, e.g. registration or administrative fees. Other universities include fees for student health care, transportation on campus, and athletic programmes (Marcucci and Usher, 2012). This system is widely used in Europe, to either keep higher education free - in principle and for tuition only - or to keep low levels of tuition fees (Marcucci and Usher, 2012).

The most striking example of the use of non-tuition fees, while retaining free tuition, is Ireland. The Irish 'student contribution' is supposed to pay for student services and 
examinations, and has increased from an original $190 €$ in 1997 to 3,000€ in 2015-2016 - its current level - thus ameliorating funding shortfalls due to the 2008 crisis without reintroducing contentious tuition fees (Citizens Information Board, 2016; Hazelkorn, 2014). This makes higher education in Ireland more expensive than in some European countries which acknowledge tuition fees, such as France or Italy (Euridyce, 2013). Ireland is even more fascinating when one considers that it abolished tuition fees in 1997, at that time equivalent to a little more than 2,000€ (Swail and Heller, 2004). The country’s so-called 'student contribution' is in all practical senses 'the tuition fee 'that dare not speak its name"' (Hazelkorn, 2014, 1347).

\section{Dual track}

Another scheme established by countries with free higher education systems, especially former communist countries, is dual-track tuition fees. Public university programmes in these systems have two tracks: one track charges no tuition fees to students while the second one charges tuition fees (Johnstone and Marcucci, 2010). The allocation to each track is merit based with high achieving students accessing the free track, while others are required to pay for the same education. This system is popular in Russia and the former communist countries of Central and Eastern Europe. What characterises these countries is that they usually have free higher education as a constitutional right, and/or experienced strong popular and political resistance to the implementation of fees (Marcucci and Usher, 2012). The dual track system, therefore, allows countries to keep the pretence of free tuition higher education, while not bearing the costs of increasing demand. The number of students accepted in the free track depends directly on the annual government budget (Johnstone and Marcucci, 2010), and is contingent on students' academic performance (Marcucci et al., 2008). Since the early 2000s, countries in East Africa - Uganda, Kenya, Tanzania - have also implemented dual track 
systems, following the success of the concept at Makerere University since 1992 (Marcucci et al., 2008). Some of these countries are, however, today charging low tuition fees in the subsidised track. Other types of dual track systems include those charging tuition fees for further education and professional programmes and/or for courses taught in a second language at free public universities, as well as those where international students are charged a tuition fee (Marcucci and Usher, 2012).

The main example of the classic dual-track system is Russia, where free higher education is guaranteed by the constitution (Johnstone and Marcucci, 2009). Financial difficulties in 1992 led to the implementation of the Law of Education - extended in 1996 that introduced cost-sharing and made the dual-track legal (Bain, 2001). By 2006, more than $50 \%$ of revenue generated by universities came from tuition fees (Johnstone and Marcucci, 2010). For many public universities, revenue from tuition fees is the second major income source after state allocations, rendering the Russian public system highly dependent on tuition fees. In fact, while in 1995-96 only $13 \%$ of students were paying fees, in 2005 over $55 \%$ of students in Russia paid for tertiary education (Johnstone and Marcucci, 2010). The dual track tuition concept has enabled Russia to absorb the increasing demand for higher education: the number of students tripled between 1992 and 2005 (Johnstone and Marcucci, 2010).

\section{Privatisation}

If in most countries worldwide the public system of higher education remains dominant, some countries have seen an important expansion of the private education system following the massification of higher education (Altbach et al., 2010). This private system is demanddriven and has become more important in terms of institution numbers and enrolment share than the public system, especially in systems with free tuition (Levy, 2006). The explanation 
is simple: as demand rises, governments are unable to keep up with the costs and so restrict student numbers in subsidised public higher education institutions, encouraging the establishment of private higher education institutions (Altbach et al., 2010). As a result, most students in these free tuition systems, especially low-income and less academically prepared students, have no choice but to attend private institutions that are by no means free since they are being crowded out of the public sector by merit-based admission criteria.

Brazil is an interesting example of a free public system that is today overshadowed by a huge and expansive private sector. Brazil has always had a well-funded public system of higher education, but was unable to keep up with massification. Between 1999 and 2005, the number of students in higher education tripled, thus forcing an expansion of the system (International Comparative Higher Education Finance and Accessibility Project, n.d.). This expansion was not led by the government, which did, however, support the establishment of an ever-growing private higher education system. As a result, the private sector absorbed most of the demand between 1998 and 2002 (Weiner, n.d.), while the elitist public sector remained small.

More recent figures show that the trend has continued (Diretoria de Estatísticas Educacionais DEED, 2015). 87 percent of higher education institutions are considered private, enrolling more than 5 million students, i.e. 74 percent of the total number of students in higher education. The private sector has become increasingly important in Brazil, resulting in a majority paying tuition fees in a country that refers to itself as free tuition.

This situation is not exclusive to Brazil: most Latin American countries that fund public higher education have acknowledged a huge growth of their private sector with increasing demand. In fact, the share of private enrolment in Latin America is around 49\%, significantly higher than the region in second place-Asia with 36\% (Levy, 2006). 


\section{Full free tuition}

Though many countries are considered free tuition, only a few really offer free tuition higher education to all their students with open access. Examples of such exceptions include the Nordic countries, in particular Finland and Norway, as Sweden and Denmark recently introduced tuition fees for international students, thus creating a type of dual-track system (Vabø and Wiers-Jenssen, 2015). Other countries sustaining free tuition open access systems include Argentina, Germany and Cuba.

\section{Characteristics of free higher education systems}

The above list of free tuition system types is far from exhaustive. Every supposedly free country seems has a unique way of understanding the meaning and extent of free tuition. The complexity of the landscape seems to have prevented any exhaustive listing of the different types of free tuition, as well as any clear and straightforward typologies to categorize them. The only existing typology was ventured by Usher (2016) in a blog article and inventoried nine types of free tuition systems. However, this only illustrates the complexity of free tuition systems and is not based on any explicit criteria coherent across types.

This work on free tuition has shown no promise in finding a clear and concise typology to categorize these systems. However, certain criteria are important to understand the context in which such systems operate, including:

- Which institutions are included in the free tuition policy: public/private, universities/vocational institutions, all degrees or only first degrees etc.

- Which students benefit from free higher education: all students, full-time students only, domestic students only, students in some fields only.

- What is paid for: tuition fees only or maintenance also, and to what extent. 
- If, when, and how tuition fees are paid for. Although the concept of free tuition prevents any financial repayment, there can be requirements from the government that students need to fulfil - including public sector work, for instance.

\section{A definition of 'free tuition higher education'}

While the concept of free tuition higher education seems initially straightforward, in practice it is intricate. If researchers were to accept its sole definition being a system where any student who graduates high school can access some type of free public higher education, very few countries would actually be considered free.

It is therefore necessary to try and reconcile these different systems to allow further research on the very singular group of countries described above. One possible definition, although it has its shortcomings, is the following: 'A free higher education system offers the possibility for undergraduate students to attend a public higher education institution without being charged tuition fees' (de Gayardon, 2018). The difficulty in such a definition resides in the complex line between the public systems that are free, except in some cases - and therefore remain by default or by law free - and those that charge tuition fees as a default, except in some circumstances.

As seen before, this definition encompasses a wide range of realities and students sometimes still have to pay high amounts in those systems. However, it gives a basis for studying countries where higher education seems to be free. By putting all these countries in a single category, it is possible to analyse their common characteristics as well as highlight their differences.

\section{Access and success in free tuition systems}

As seen before, countries that sustain free tuition higher education come in many different shapes and forms - including in terms of economic development, geographical location, 
extent of free higher education, and access policies. As such, comparison is somewhat complicated by the many differing factors and unique national contexts. However, comparison can still offer an insight into the diversity of higher education outcomes and thus help improve the knowledge and understanding of free higher education globally.

As a starting point to the study of free tuition higher education, this article takes a first look at access and success in this particular set of countries. Access is often cited by students and policy-makers as the main reason to establish a free tuition system: it is believed that by abolishing the financial barrier, more students and students from more diverse backgrounds particularly students from poorer backgrounds - will access higher education. In effect, this theory has been debunked in several contexts.

This theory is once again put to the test, but in a comparative perspective, using data from the UNESCO Institute for Statistics: the gross enrolment ratio to evaluate participation and the graduation rate to evaluate success. The data reported are the latest available for the period 2012-2014.

The comparison is undertaken for three categories of free higher education systems: countries that have implemented dual-track systems for domestic students, countries whose free public system has restricted access - which includes highly privatised systems described above, and countries that are free for all (or with only non-tuition fees) and open access. This allows an insight into the overall access and success in free tuition systems as well as possible differences based on the type of free system analysed. Missing from this analysis are countries for which UNESCO data was unavailable and/or countries whose free system design was unique or hard to categorise based on desk research.

\section{Dual-track countries}


As seen in Figure 3, there is a wide diversity of participation rates among countries that have dual-tracks systems. Countries in Eastern Europe have achieved relative success with their dual track systems, with enrolment rates up to 80 percent. On the contrary, countries in Central Asia have found limited success, while dual-track countries in Africa remain elitists, with enrolment rates below 10 percent. Although these countries have designed similar financing system around the principle of higher education, it seems that their geographical location, as well as probably their level of economic development, are more important determinants of participation levels.

Where available, Figure 3 also provides data on success in higher education as proxied by graduation rates. This graph tells us two important things. First, like for participation, there seems to be a wide range of graduation ratios within the group of dualtrack countries. However, the geographic clusters are less clear, with some countries in Eastern Europe graduating close to 60 percent of their cohorts and others graduating 30 percent or less of their students. Second, there is no correlation between participation rates and graduation rates.

\section{[Figure 3 about here]}

\section{Restricted access countries}

This category includes countries with free public higher education as well as merit-based access to public higher education and /or more than 50 percent of their higher education enrolment in private institutions - as indicated by UNESCO data. It excludes those that were already categorised as dual-track due to the financing of their public system.

Figure 4 shows that participation rates in free countries with restricted access to their public system vary widely from close to 80 percent to less than 10 percent. There does not seem to be any trend in this small cluster of countries in terms of participation by size, 
location or development level. Graduation rates also vary significantly with Kazakhstan and Croatia above 40 percent; Cyprus, Brazil and Ecuador around 25 percent; while others are below 10 percent. The small number of data points for this category prevents any further generalization, but the data we have seem to suggest a lack of a common trend among these countries.

\section{[Figure 4 about here]}

\section{Free or non-tuition fees countries with open access policies}

The data on access and success for free open access countries have been graphed in Figure 5, including many fully free countries and some with non-tuition fees. This figure shows that participation levels are smoothly distributed and range from above 85 percent for Finland and Greece to below 5 percent for some African countries. Like for dual-track countries, there is a geographical trend, with most countries above 60 percent participation being in Europe - except for Argentina, Uruguay, and Saudi Arabia. At the other end of the distribution, many countries where higher education remains elitist are located in Africa. This hints at the fact that higher education participation might be more correlated with development levels or culture than with a free tuition policy.

There is also no clear trend in graduation rates across countries. Graduation rates vary amongst countries and are not correlated with participation. There also seems to be less geographical convergence than for participation, although overall graduation rates in Europe are higher.

[Figure 5 about here]

Access, success, and free higher education 
The three graphs above help tell the global story of free tuition higher education. Although many countries claim free higher education systems, their participation levels vary widely, countering the statement that free higher education systematically improves access. Participation levels, in fact, seem to be better correlated with economic development levels and cultural expectations.

But access is only the beginning of the story, and emphasis should be put on the success - i.e. graduation - of individuals who enter higher education. The graphs above show little coherence in graduation rates among countries with free higher education systems. Although there is some regional convergence in participation, it is less pronounced in the case of graduation rates.

What this tells us is that free higher education alone, whatever form it takes, does not seem to be generating systems that are consistently good at widening participation and guaranteeing success for all. In that sense, free higher education should not be considered a miracle solution: it can only succeed, like other cost-sharing policies, if appropriately supported by access-specific policies - such as carefully designed financial aid polices, improved quality in the secondary system, remediation courses, or affirmative action quotas.

\section{Conclusion}

As higher education takes prominence in the knowledge society, arguments about its financing will become more prominent, particularly because they are linked to other controversial issues such as access and quality. In the global discussion on tuition fees, countries offering free tuition higher education seem to have been somewhat forgotten. This article sheds light on the commonalities and differences of this peculiar group of countries from the perspective of current financing trends. 
Free tuition systems are diverse geographically and in economic status, but all are anchored in strong philosophical and historical traditions. Whether it is because they consider higher education a right or value equal opportunities, these societies are fiercely attached to free higher education. However, faced with financial issues, governments have had to establish alternative schemes to both protect free public higher education and provide some financial sustainability. As a result, there is no indication that free tuition systems are performing exceptionally well in guaranteeing access to all and fostering student success.

When Chilean or English students demonstrate, calling for free higher education, they seem to forget to look at these real-world examples. Systems that offer free tuition higher education are not exempt from issues of financing, access, and quality. Theoretically, issues experienced by free systems can be seen through the lens of the 'Iron Triangle.' This framework introduced by Sir John Daniel highlights the three main issues facing higher education today_cost, access, and quality—and how they interact (Daniel et al., 2009). This concept intrinsically acknowledges that an equilibrium is challenging to achieve, as trying to improve one of these aspects usually means altering another or both of the other pillars. Therefore, free tuition higher education systems, which limit the cost side of the triangle as government budgets determine the cost of education for students, are deemed to face challenges in access and quality. In particular, financing constraints on the part of governments could lead to a restriction of the number of students accepted free of charge restricting access - or to the reduction of the per-student allocation to institutions - thus reducing the quality of education. This theory calls for more research in free tuition systems regarding access and quality, to determine to what extent, and how, free tuition policies affect other pillars of higher education.

As countries contemplate the establishment of free tuition higher education, they should acknowledge that it is not a miracle means of improving access. Free higher education 
might be a worthwhile policy as part of a stronger set of policies aimed at improving access, but alone it might not achieve anything but the fulfilment of philosophical ideals. In addition, policy-makers should be wary of the short-term difficulties in establishing free tuition systems, as experienced recently by both Chile and the Philippines. In the past two years, Chile has failed to implement free tuition for all, restricting it to some institutions and the 60 poorest students, because of budgetary constraints. In the Philippines, proponents of free tuition criticised the current policy format for fostering inequity, even before its formal implementation. The main problem with free higher education remains how expensive such a policy is in an age of massification and government austerity. 


\section{References}

Adrian, W. (1983) 'The tuition dilemma in the Latin American University', International Review of Education 29(4): 449-464.

Altbach, P. G., Reisberg, L., and Rumbley, L. E. (2010) Trends in global higher education: Tracking an academic revolution, Rotterdam: Sense Publishers.

Bain, O. (2001) 'The cost of higher education to students and parents in Russia: Tuition policy issues', Peabody Journal of Education 76(3-4): 57-80.

Becker, G. S. (1975) Human capital: A theoretical and empirical analysis, with special reference to education (2nd ed), New York: Columbia University Press for NBER.

Becker, G. S. (2007) 'Human capital', in D. R. Henderson (ed.) The concise encyclopedia of economics, Indianapolis, IN: Liberty Fund.

Blaug, M. and Woodhall, M. (1978) 'Patterns of subsidies to higher education in Europe', Higher Education 7(3): 331-361.

Bloom, D. E., Hartley, M., and Rosovsky, H. (2007) 'Beyond private gain: The public benefits of higher education', in J. J. F. Forest and P. G. Altbach (eds.) International handbook of higher education, Dordrecht: Springer, pp. 293-308.

Brennan, J., Durazzi, N., and Séné, T. (2013) Things we know and don't know about the wider benefits of higher education: a review of the recent literature. London, UK: Department for Business, Innovation and Skills. BIS Research Paper no. URN BIS/13/1244.

Citizens Information Board (2016) Third-level student fees and charges. http://www.citizensinformation.ie/en/education/third_level_education/fees_and_supp orts_for_third_level_education/fees.html, accessed 20 March 2018.

Coleman, J. S. (1969) 'Equality of educational opportunity, reexamined', Socio-Economic Planning Sciences 2(2): 347-354. 
Collins, C. S. and Rhoads, R. A. (2008) 'The World Bank and higher education in the developing world: the cases of Uganda and Thailand', in D. P. Baker and A. W. Wiseman (eds.) The worldwide transformation of higher education, Bingley: JAI, pp. $177-222$.

Daniel, J., Kanwar, A., and Uvalić-Trumbić, S. (2009) ‘Breaking higher education’s iron triangle: Access, cost, and quality', Change: The Magazine of Higher Learning 41(2): $30-35$.

de Gayardon, A. (2018) 'Free higher education: myths and realities', in P. N. Texeira and J. C. Shin (eds.) Encyclopedia of international higher education systems and institutions. Amsterdam: Springer Netherlands.

Dewey, J. (1916). 'Democracy and education (selection)', in S. M. Cahn, Classic and contemporary readings in the philosophy of education, New York: Oxford University Press, pp. 228-264.

Diretoria de Estatísticas Educacionais DEED (2015) Resumo técnico: Censo da educaçao superior 2013. Brasília: Instituto Nacional de Estudos e Pesquisas Educacionais Anísio Teixeira.

Euridyce (2013) National student fee and support systems. Brussels: European Commission Education and Training.

Forsyth, A. and Furlong, A. (2000) Socioeconomic disadvantage and access to higher education, Bristol: The Policy Press and the Joseph Rowntree Foundation.

Gutmann, A. (1999) 'Democratic education (selection)', in S. M. Cahn, Classic and contemporary readings in the philosophy of education, New York: Oxford University Press, pp. 328-344.

Hazelkorn, E. (2014) 'Rebooting Irish higher education: policy challenges for challenging times', Studies in Higher Education 39(8): 1343-1354. 
Head, J. G. (1966) ‘On merit goods’, FinanzArchiv: Public Finance Analysis 25(1): 1-29.

Heymann, J. and McNeill, K. A. (2013) Changing children's chances: New findings on child policy worldwide. Los Angeles: World Policy Analysis Center.

Institute for Higher Education Policy (1998) Reaping the benefits: Defining the public and private value of going to college. Washington, DC: Author.

International Comparative Higher Education Finance and Accessibility Project (n.d.) Higher education finance and cost sharing in Brazil. Buffalo, NY: SUNY Buffalo.

James, R. (2002) Socioeconomic background and higher education participation: An analysis of school students' aspirations and expectations. Canberra: Department of Education, Science and Training.

Johnstone, D. B. and Marcucci, P. N. (2009) 'Tuition fee policies in a comparative perspective', in M. Tight, K. H. Mok, J. Huisman, and C. Morphew (eds.) The Routledge international handbook of higher education, New York: Routledge.

Johnstone, D. B. and Marcucci, P. N. (2010) Financing higher education worldwide: Who pays? Who should pay?, Baltimore, MD: Johns Hopkins University Press.

Levy, D. C. (2006) 'The private fit in the higher education landscape', in J. J. F. Forest and P. G. Altbach (eds.) International handbook of higher education Dordrecht: Springer, pp. 281-291.

Lusardi, A. and Mitchelli, O. (2007) 'Financial literacy and retirement preparedness: Evidence and implications for financial education', Business Economics 42(1): 35-44.

Mankiw, N. G., Romer, D., and Weil, D. N. (1990) A contribution to the empirics of economic growth. Cambridge, MA: National Bureau of Economic Research. NBER Working paper Series no. 3541. 
Marcucci, P. N. (2013) 'The politics of student funding policies from a comparative perspective', in D. E. Heller and C. Callender (eds.) Student financing of higher education: a comparative perspective. New York: Routledge, pp. 9-31.

Marcucci, P. N., Johnstone, D. B., and Ngolovoi, M. (2008) 'Higher educational cost-sharing, dual-track tuition fees, and higher educational access: The East African experience', Peabody Journal of Education 83(1): 101-116.

Marcucci, P. N. and Usher, A. (2012). 2011 year in review: Global changes in tuition fee policies and student financial assistance. Toronto: Higher Education Strategy Associates.

Marginson, S. (2007). 'The public/private divide in higher education: A global revision', Higher Education 53(3): 307-333.

Marshall, T. H. (1950) Citizenship and social class and other essays, London: Cambridge University Press.

Mincer, J. (1981) Human capital and economic growth. Cambridge, MA: National Bureau of Economic Research. NBER Working Paper No. 803.

Musgrave, R. A. (1959) The theory of public finance: A study in public economy, New York: McGraw-Hill.

Organisation for Economic Co-operation and Development (2014) Education at a glance 2014: OECD indicators. Paris: Author.

Peracchi, F. and Welch, F. (1994) 'Trends in labor force transitions of older men and women', Journal of Labor Economics 12(2), 210-242.

Power, E. J. (1982) Philosophy of education: studies in philosophies, schooling, and educational policies, Englewood Cliffs, NJ: Prentice-Hall.

Pusser, B. (2002) 'Higher education, the emerging market, and the public good', in P. A. Graham and N. C. Stacey (eds.) The knowledge economy and postsecondary 
education: Report of a workshop, Washington, DC: National Academies Press, pp. $105-125$.

Putnam, R. (2001) 'Social capital: Measurement and consequences', Canadian Journal of Policy Research 2(1): 41-51.

Rawls, J. (1999) A theory of justice - Revised edition, Cambridge, MA: Belknap Press of Harvard University Press.

Rosenstone, S. J. and Hansen, J. M. (1993) Mobilization, participation, and democracy in America, New York: Macmillan.

Samuelson, P. A. (1954) 'The pure theory of public expenditure', The Review of Economics and Statistics 36(4): 387.

Schultz, T. W. (1961) 'Investment in human capital', The American Economic Review 51(1): $1-17$.

Stiglitz, J. E. (1999) 'Knowledge as a global public good', in I. Kaul, I. Grunberg, and M. A. Stern (eds.) Global public goods: International cooperation in the 21st century, New York, NY: Oxford University Press, pp. 308-324.

Swail, W. S. and Heller, D. E. (2004) Changes in tuition policy: Natural policy experiments in five countries. Montreal: The Canada Millennium Scholarship Foundation.

Tilak, J. B. G. (2004) Higher education between the state and the market. Paper presented at the UNESCO Forum on Higher Education, Research and Knowledge; Paris, France.

UNESCO Institute for Statistics (2017) UIS Statistics - Education. http://data.uis.unesco.org/, accessed 20 March 2018.

Usher, A. (2016) A typology of "free tuition". World View, 13 March, https://www.insidehighered.com/blogs/world-view/typology-\%E2\%80\%9Cfreetuition\%E2\%80\%9D, accessed 19 March 2016 
Uslaner, E. M. (n.d.) Civic engagement in America: Why people participate in political and social Life. College Park, MD: Knight Civic Engagement Project, The Democracy Collaborative at the University of Maryland, and the Centre for the Study of Voluntary Organizations and Service at Georgetown University.

Vabø, A. and Wiers-Jenssen, J. (2015) 'Different approaches to fees for international students', University World News, 3 April.

Vossensteyn, H. (2009) 'Challenges in student financing: State financial support to students A worldwide perspective', Higher Education in Europe 34(2): 171-187.

West, C. (2013) 'To charge or not to charge? That is tuition', International Educator 22(4): $34-43$.

Weiner, B. (n.d.) The development and privatization of tertiary education in Brazil: Uma novela dramática. https://www.academia.edu/1705286/The_Development_and_Privatization_of_Tertiar y_Education_In_Brazil_Uma_Novela_Dram\%C3\%A1tica, accessed 20 March 2018. Woolley, F. (2006) Why public goods are a pedagogical bad. Ottawa: Carleton University, Department of Economics. Carleton Economic Papers no. 06-06.

World Policy Analysis Center (2017) Is education tuition-free? http://www.worldpolicycenter.org/policies/is-education-tuition-free/is-primaryeducation-tuition-free, accessed 20 February 2017. 
Figure 1 - Countries with free tuition higher education

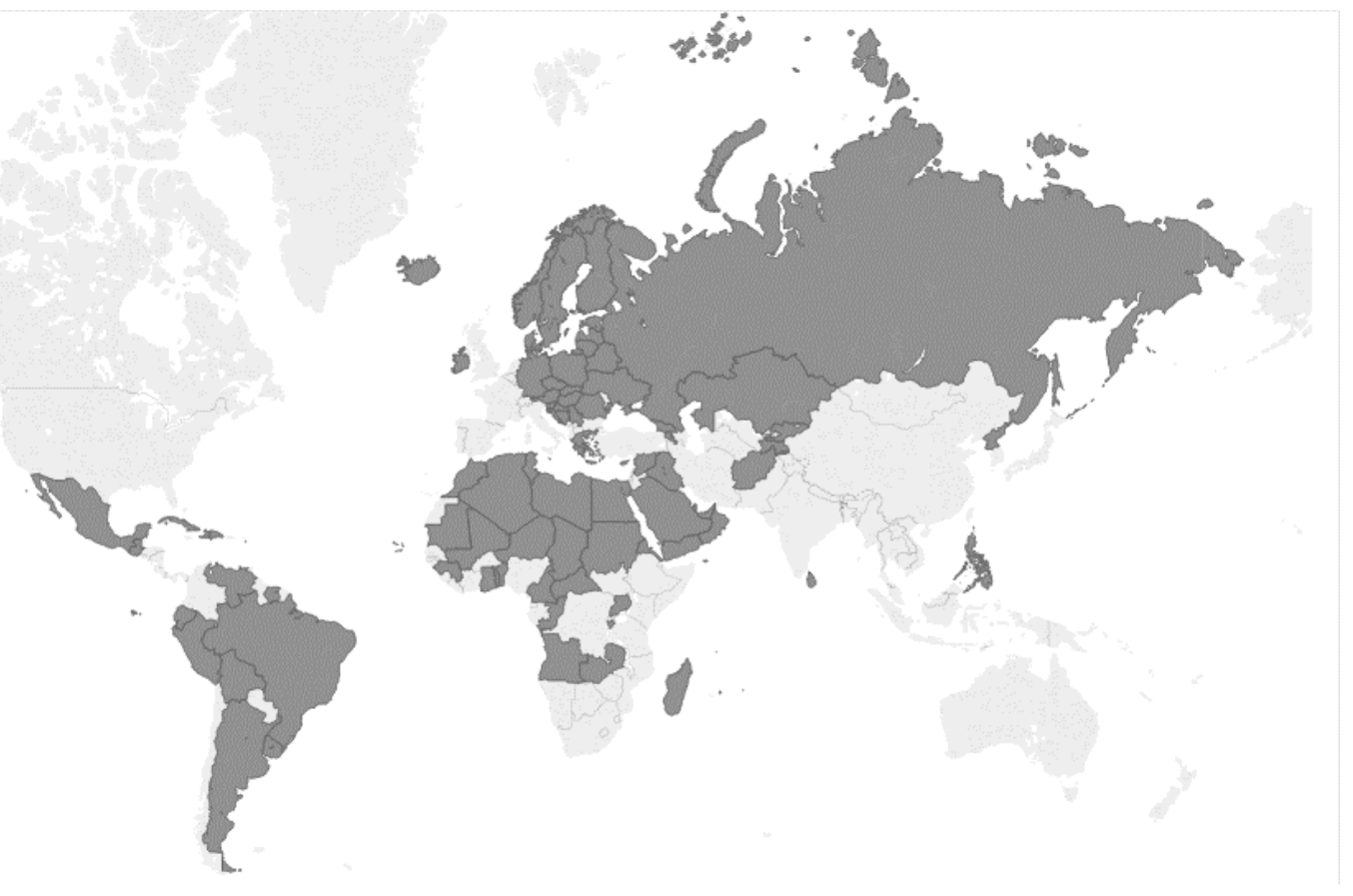


Figure 2 - Percentage of countries with free higher education per development level

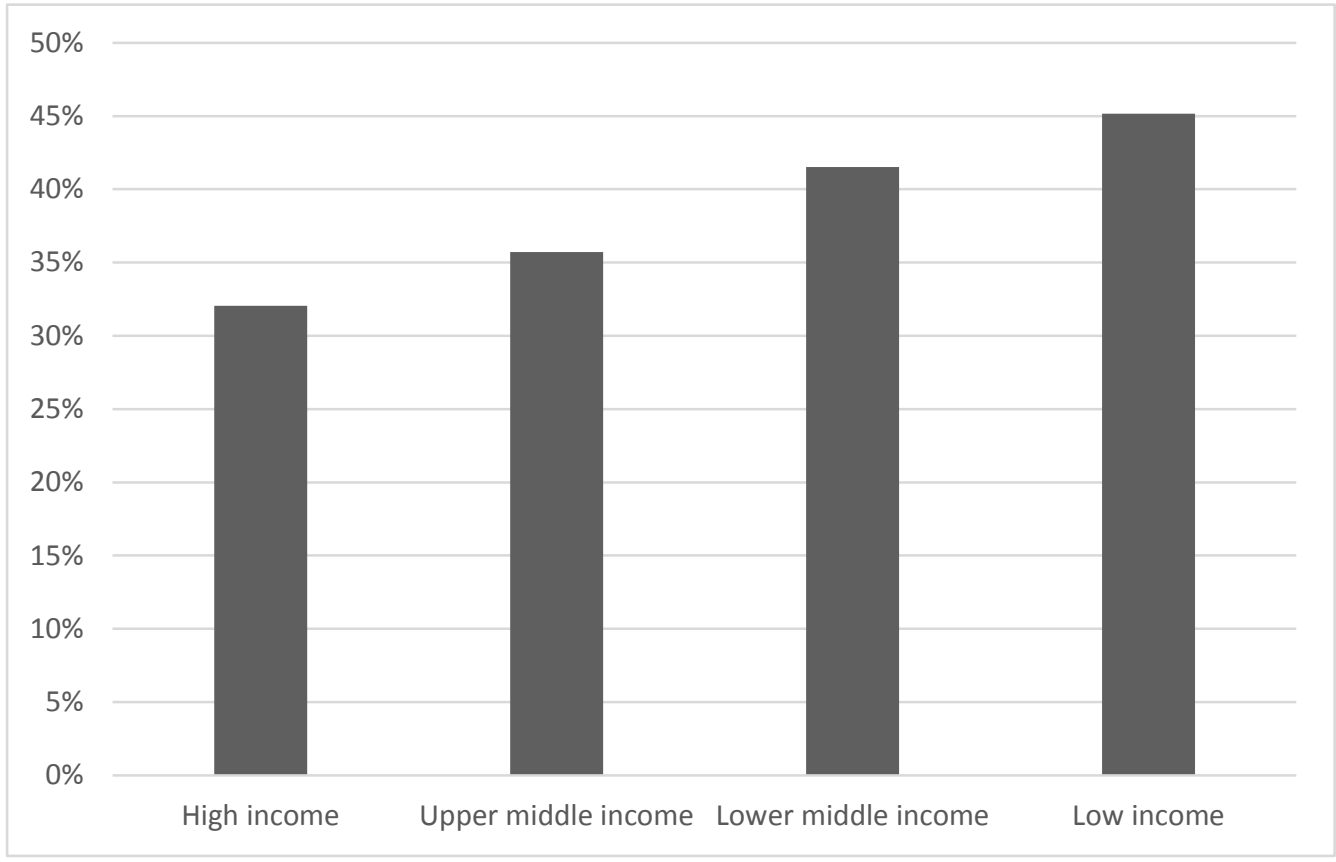

Source: The World Bank 
Figure 3 -Access and success in countries with dual-track free higher education systems (\%)

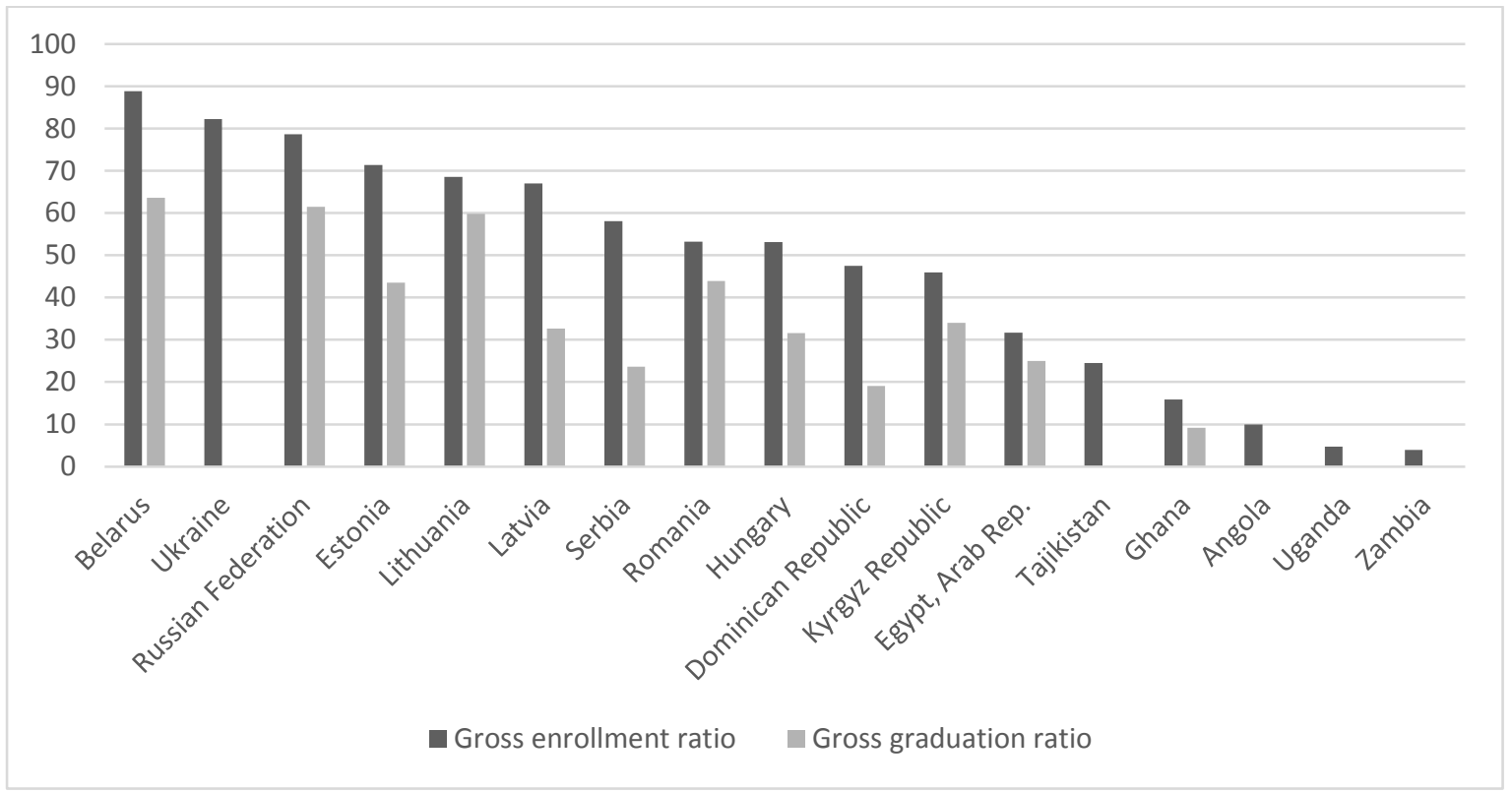

Source: (UNESCO Institute for Statistics, 2017)

Latest available data between 2014 and 2012. 
Figure 4-Access and success in countries with free higher education systems and selective access (\%)

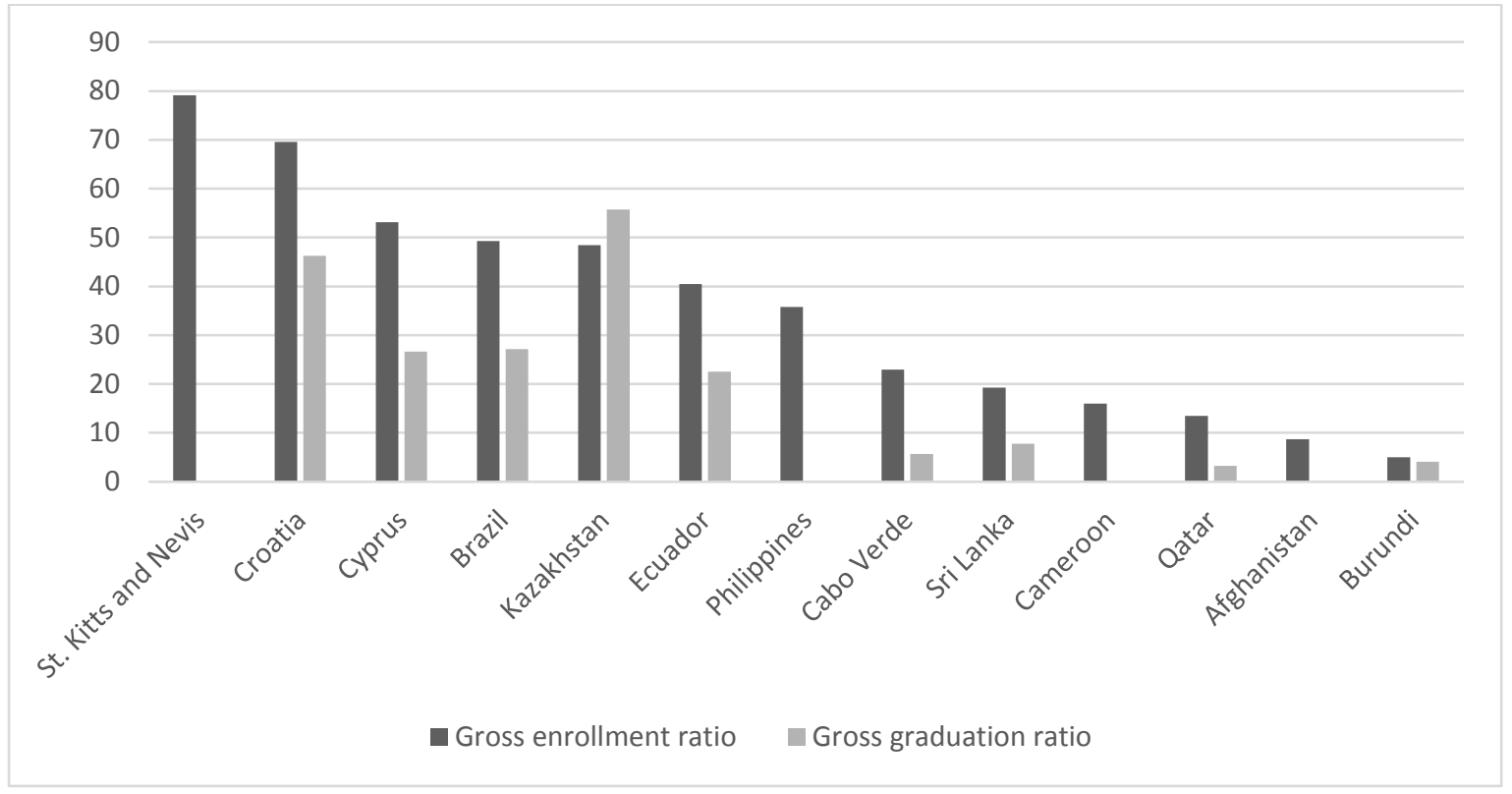

Source: (UNESCO Institute for Statistics, 2017)

Latest available data between 2014 and 2012. 
Figure 5 - Access and success in free open access countries (\%)

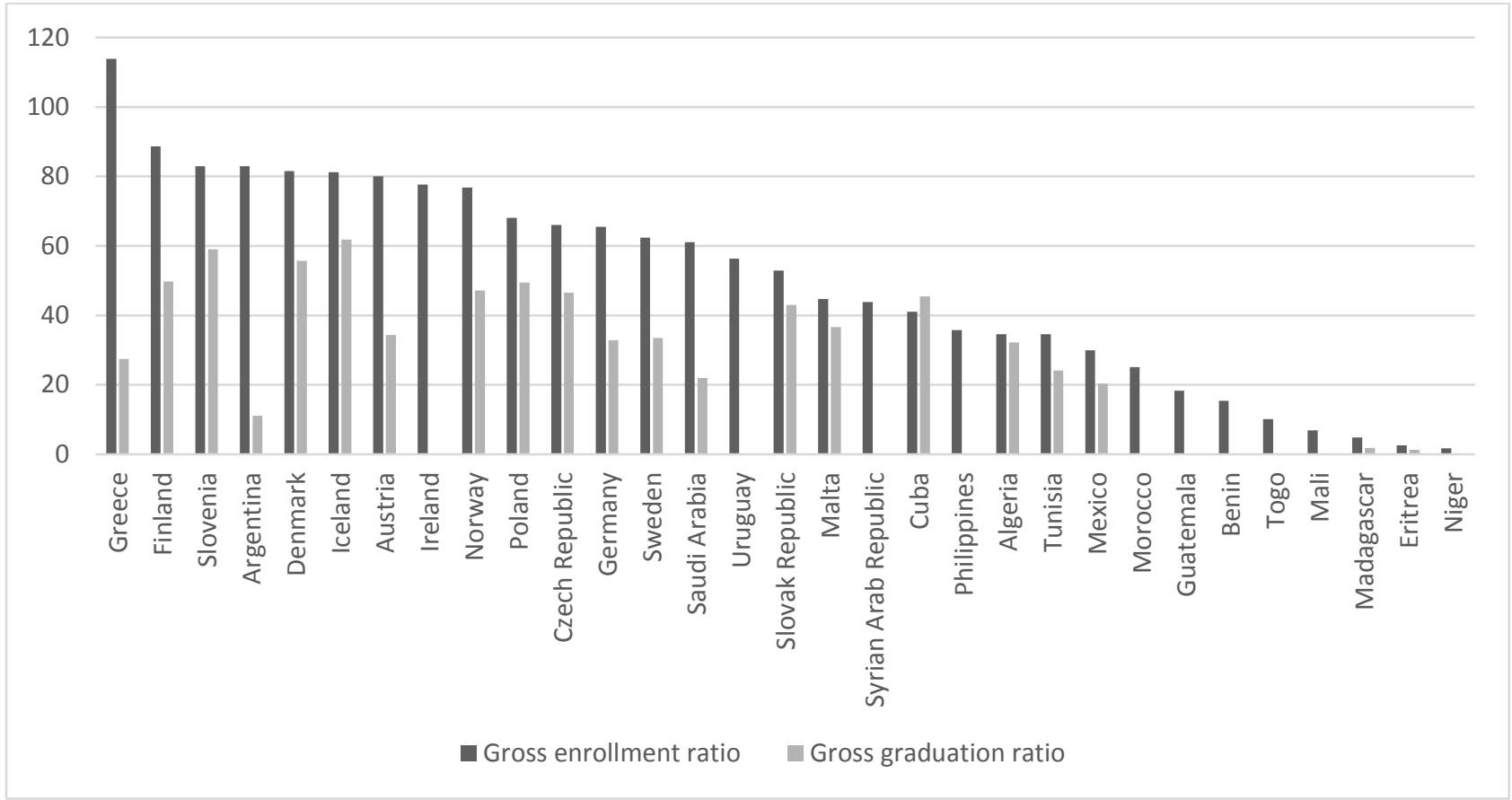

Source: (UNESCO Institute for Statistics, 2017)

Latest available data between 2014 and 2012. 